\title{
Unusual cyclosporin related neurological complications in recipients of liver transplants
}

\author{
Maria Roberta Cilio, Olivier Danhaive, Jean Francois Gadisseux, Jean Bernard Otte, \\ Etienne M Sokal
}

\begin{abstract}
In a series of 256 recipients of paediatric liver transplants, from 1984 to 1990 , four patients presented with sudden onset seizures not explained by conventional work-up. None had a family or personal history of seizures. Infectious causes were excluded. There were no glucose or electrolyte disturbances. Seizures were not induced by systemic or intracranial hypertension. One child out of four had transient white matter and cortex focal lesions on computed tomography of the brain. One to 10 days before seizures all four children presented with supratherapeutic concentrations of serum cyclosporin that were determined by a non-specific method that measured the parent compound plus its metabolites. The supratherapeutic concentrations were not found with the specific method measuring cyclosporin alone. It is concluded that these seizures may correspond to a toxic effect of cyclosporin, probably due to one or several metabolites, as suggested by the discrepancy between specific and non-specific methods of determination.

(Arch Dis Child 1993; 68: 405-407)
\end{abstract}

Cyclosporin is the most widely used immunosuppressor in solid organ transplantation. It is known to exert various toxic effects on the central nervous system, including psychiatric disorders, lethargy, tremor, visual disturbances, cerebellar ataxia, and seizures. The incidence and severity of these neurotoxic manifestations seems to be higher after liver compared with other organ transplantation..$^{1-3}$

Neurological symptoms, and especially seizures, have been correlated with several concurrent factors such as high doses of methylprednisolone treatment, ${ }^{4}$ hypertension particularly in children, ${ }^{5}$ hypomagnesaemia, ${ }^{6}$ and hypocholesterolaemia. ${ }^{1}$ We report four patients in which seizures occurred 20 days to three months after orthotopic liver transplantation that could not be explained by electrolyte or other biochemical abnormalities, major haemodynamic disturbances, bacterial, viral, or fungal central nervous system infections, intracranial haemorrhage, hypertension, or any previous central nervous system disease.

\section{Patients and methods}

Between 1 April 1984 and 31 December 1990, 256 orthotopic liver transplantations were performed in 210 paediatric patients. The surgical technique has been described previously..$^{7-9}$ Immunosuppression was started in the operating theatre when the patient was given the first dose of cyclosporin ( $2 \mathrm{mg} / \mathrm{kg}$ for one hour). In the intensive care unit, after evidence of sufficient urinary output, the drug was given as a continuous 24 hour infusion, at an initial dose of $2 \mathrm{mg} / \mathrm{kg}$. The dose was progressively increased thereafter to reach a serum concentration of 100 to $150 \mathrm{ng} / \mathrm{ml}$, as determined by specific radioimmunoassay (Cyclo-Trac, Incstar Corp). Once oral feeding was allowed, cyclosporin was given orally and progessively increased to replace intravenous infusion.

Methylprednisolone was given intravenously during the first week and followed a decreasing dosage schedule from $100 \mathrm{mg}$ the first day (four divided doses) to reach, after one week, $1 \mathrm{mg} / \mathrm{kg}$ for the first month (two divided doses) and 0.75 $\mathrm{mg} / \mathrm{kg}$ between one and three months. ${ }^{9}$ Azathioprine was started from day 1 , at a dosage of 1.5 $\mathrm{mg} / \mathrm{kg}$, according to the individual haematological tolerance.

Serum concentrations of cyclosporin were measured daily by two methods: (i) a fluorescence polarisation immunoassay (Abbott) using a polyclonal antibody that measured the combined concentration of native cyclosporin and its metabolites (non-specific assay, therapeutic range 40$400 \mathrm{ng} / \mathrm{ml}$ ) and (ii) a radioimmunoassay (CycloTrak, Incstar Corp) using a monoclonal antibody that measured only native cyclosporin (specific assay, therapeutic range $25-150 \mathrm{ng} / \mathrm{ml}$ ).

\section{Case reports}

Four of 256 patients developed cyclosporin related convulsive episodes. Two had transplantation for extrahepatic biliary atresia cirrhosis, one for tyrosinaemia,${ }^{10}$ and one for cryptogenic cirrhosis, and none had a previous history of neurological disease or seizures. Age, clinical presentation, and outcome of the neurological disease are shown in table 1. Appreciably raised blood cyclosporin concentrations had been found in the four patients three to 12 days before the onset of seizures. Maximum serum concentrations measured by the non-specific method reached $966 \mathrm{ng} / \mathrm{ml}, 800 \mathrm{ng} / \mathrm{ml}$, and over $1000 \mathrm{ng} / \mathrm{ml}$ (two patients) respectively, with serum concentrations measured by the specific method of $231 \mathrm{ng} / \mathrm{ml}, 403 \mathrm{ng} / \mathrm{ml}, 157 \mathrm{ng} / \mathrm{ml}$, and $150 \mathrm{ng} / \mathrm{ml}$ respectively. In all four children concentrations had returned to normal values within one to three days, before onset of seizures. No patient had appreciable fluid overload before seizures and blood pressure was within the normal range in three patients and mildly raised in one $(130 / 100 \mathrm{~mm} \mathrm{Hg})$. One patient had concomitant moderate renal function impairment. No other current medical or surgical
Paediatric Hepatology, UCL

St Luc 1301, 10 Avenue
Hippocrate, B 1200 Brussels,

Belgium.

Accepted 1 October 1992 
Table 1 Clinical presentation, treatment, and outcome

\begin{tabular}{|c|c|c|c|c|c|}
\hline $\begin{array}{l}\text { Case } \\
\text { No }\end{array}$ & $\begin{array}{l}\text { Age } \\
\text { (years) }\end{array}$ & $\begin{array}{l}\text { Time from } \\
\text { transplant } \\
\text { to seizures } \\
\text { (days) }\end{array}$ & Neurological presentation & Treatment & Outcome \\
\hline 1 & 8 & 86 & Generalised, tonic-clonic seizures & $\begin{array}{l}\text { Lorazepam, phenobarbitone } \\
(8 \text { months })\end{array}$ & $\begin{array}{l}\text { Alive and well and } \\
\text { off treatment (12 } \\
\text { months) }\end{array}$ \\
\hline 2 & 4 & 67 & $\begin{array}{l}\text { Irritability, abnormal behaviour, partial, secondary } \\
\text { generalised tonic-clonic seizures, status epilepticus }\end{array}$ & $\begin{array}{l}\text { Lorazepam, phenobarbitone, } \\
\text { phenytoin }\end{array}$ & $\begin{array}{l}\text { Alive and well and } \\
\text { off treatment }\end{array}$ \\
\hline 3 & $2 \cdot 5$ & 61 & $\begin{array}{l}\text { Partial, secondary generalised tonic-clonic seizures, } \\
\text { postictal hemiparesis }\end{array}$ & Midazolam, phenobarbitone & $\begin{array}{l}\text { Died, adenovirus } \\
\text { hepatitis }^{23}\end{array}$ \\
\hline 4 & 9 & 20 & $\begin{array}{l}\text { Partial, secondary generalised tonic-clonic seizures, } \\
\text { recurrence after } 13 \text { days }\end{array}$ & Lorazepam, phenytoin & $\begin{array}{l}\text { Alive and well and } \\
\text { off treatment }\end{array}$ \\
\hline
\end{tabular}

transplantation related complications were present at the time of onset. Serum cholesterol, magnesium, and glucose concentrations were normal in all four patients. Cerebrospinal fluid and paraclinical investigations at the time of the seizures are shown in table 2 .

\section{Discussion}

Since its introduction in 1978 as the most potent inhibitor of allograft rejection in organ transplantation, cyclosporin has been associated with various adverse reactions, for example nephrotoxicity and hypertension. Some patients may also develop neurological side effects, mainly seizures and tremors. Seizures have been reported to occur in $1 \cdot 8 \%$ of kidney, ${ }^{11} 5 \cdot 5 \%$ of bone marrow, ${ }^{12}$ and in up to $25 \%$ of liver transplant recipients receiving cyclosporin. ${ }^{1313}$ This latter incidence might be caused by an increased permeability of the blood-brain barrier because of liver failure. ${ }^{214} 15$

Although toxicity of cyclosporin may be related to raised blood circulating concentrations, side effects and central nervous system toxicity may also occur when blood concentrations are in the therapeutic range. With the method measuring native cyclosporin only we aim for values around 100 to $150 \mathrm{ng} / \mathrm{ml}$ in the immediate period after transplant. Dose adjustments may, however, be particularly hazardous in liver transplant recipients because of variations in enteric reabsorbtion of the drug, liver function and metabolism, and renal function. Considerable variations between specific and non-specific concentrations are usually observed for the same reasons. In addition, the serum concentrations poorly reflect the cyclosporin concentration in the tissues, and these concentrations may vary in a delayed manner, according to the degree of drug fixation to lipids.

Associated factors may enhance neurotoxicity, for example methylprednisolone bolus infusions, ${ }^{4}$ hypomagnesaemia ${ }^{6}$ aluminium overload, and hypertension. ${ }^{5}$

We observed that in one child (case 4) the seizures were preceded by nephrotoxicity and in another patient (case 1) the seizures were accompanied by mild systemic hypertension. We agree with de Groen et al in concluding that the seizures were not the result of hypertensive encephalopathy ${ }^{1}$; convulsions and systemic hypertension, rather than having a cause and effect relation, can be considered as coincident side effects of cyclosporin toxicity. In support of that, funduscopic examination in our patients at the time of seizures was strictly normal.

Three of the four patients had normal serum cholesterol concentrations, and no determination was available in the fourth patient at the time of seizures. The toxicity could therefore not be attributed to a higher free plasma concentration of the drug, nor to an increased binding to low density lipoprotein particles delivering the drug to the astrocytes, as suggested previously in patients with cyclosporin toxicity and low cholesterol concentrations. ${ }^{16}$ Cyclosporin induced release of endothelin, a neuropeptide acting on vascular smooth muscle and causing intense vasoconstriction, has been incriminated in the neurotoxicity of the drug, but no evidence currently exists to corroborate this hypothesis in clinical settings. ${ }^{17}$

Because excretion of cyclosporin is predominantly in the bile, liver function interferes with the elimination of cyclosporin metabolites, which may reach very high concentrations compared with the concentration of native cyclosporin in liver transplant patients with graft dysfunction. ${ }^{18}$

In our patients, seizures occurred within three months of surgery. While serum concentrations of native cyclosporin were normal or only mildly increased, all four patients had very high concentrations of cyclosporin plus its metabolites; this shows the importance of measuring metabolite concentrations in these patients. These metabolites, rather than the native drug itself, may be responsible for toxicity, as previously suggested for the metabolite $17 .{ }^{19}$ The most striking finding in our series is that the toxic concentrations were found up to 10 days before seizures and had

Table 2 Paraclinical and cerebrospinal fuid investigations

\begin{tabular}{lllll}
\hline $\begin{array}{l}\text { Case } \\
\text { No }\end{array}$ & Electroencephalography & Computed tomography & $\begin{array}{c}\text { Examination of } \\
\text { fundus of eye }\end{array}$ & Cerebrospinal fuid \\
\hline 1 & $\begin{array}{l}\text { Diffuse, slow waves } \\
\text { Left sided, continuous } \\
\text { spike and waves } \\
\text { Left sided, spikes and } \\
\text { waves }\end{array}$ & $\begin{array}{l}\text { Normal } \\
\text { Day 0: normal; day 3: multiple white matter, } \\
\text { hypodense areas; day 13: normal }\end{array}$ & $\begin{array}{l}\text { Nild cortical atrophy } \\
\text { Normal }\end{array}$ & $\begin{array}{c}\text { Normal } \\
\text { Normal }\end{array}$ \\
3 & Left sided, slow waves & Normal & Normal & $\begin{array}{c}\text { Lymphocytes subnormal at } \\
8 / \text { microscopic field and protein } \\
0 \cdot 68 \text { g/l (normal } 0 \cdot 20-0 \cdot 55)\end{array}$ \\
4 & & Normal & Normal \\
\hline
\end{tabular}


normalised at the time of seizure occurrence in three out of the four patients. This time interval before the onset of neurological symptoms may represent the delay required for the accumulation of cyclosporin metabolites in the brain, thereafter causing interference with neurotransmission. ${ }^{20}$ In two patients (cases 2 and 4), in which the concentration of cyclosporin in the cerebrospinal fluid was measured it was undetectable, but due to the lipophilic nature of cyclosporin, cerebrospinal fluid concentrations may not reflect brain tissue concentrations.

Only one of our patients developed abnormalities on computed tomography, three days after seizure, which could be related to cyclosporin intoxication. ${ }^{1172122}$ Both occipital and frontal hypodensities resolved to normal after 10 days; these might have been caused by increased water content with consequent axonal swelling. It is possible, as suggested by Truwit et al, that raised concentrations of cyclosporin induce a local vasospasm that is endothelin mediated and results in mild, reversible ischaemia with consequent white matter oedema. ${ }^{17}$ Cyclosporininduced seizures are generally well controlled by antiepileptic drugs, although one patient presented with status epilepticus that was initially refractory to treatment.

All four children recovered completely from their neurological disorders; one of them (case 3) died later from adenovirus hepatitis ${ }^{23}$ but she had no neurological sequelae.

We conclude that cyclosporin metabolites may play a significant part in central nervous system toxicity, and this toxicity may be due to a progressive accumulation in more vulnerable regions of the brain and particularly in the white matter, which has a high lipid content.

Further studies of different cyclosporin metabolites using mass spectrometry may help in identifying more precisely the responsible metabolites.

1 de Groen PC, Aksamit AJ, Rakela J, Forbes GS, Krom RA. Central nervous system toxicity after liver transplantation. 1987; 317: 861-6.
2 Tollemar J, Ringdén O, Ericzon B-G, Tyden G. Cyclosporineassociated central nervous system toxicity. $N$ Engl $\mathcal{F} M e d$ 1988; 318: 788-9.

3 Vogt DP, Lederman RJ, Carey WD, Brougan TA. Neurologic complications of liver transplantation. Transplantation 1988; 45: 1057-61.

4 Durrant S, Chipping PM, Palmer S, Gordon-Smith EC. Cyclosporin A, methylprednisolone, and convulsions.

5 Joss DV, Barrett AJ, Kendra JR, Lucas CF, Desai S. Hypertension and convulsion in children receiving cyclo-

6 Thompson CB, June CH, Sullivan KM, Donnal Thomas E. Association between cyclosporin neurotoxicity and hypomagnesaemia. Lancet 1984; ii: 1116-20.

7 Otte JB, Yandza T, de Ville de Goyet J, Tan KC, Salizzoni M, de Hemptinne B. Pediatric liver transplantation: report of 52 patients with a two-years survival of $86 \%$. F Pediatr Surg 1988; 23: $250-3$.

8 Otte JB, de Ville de Goyet J, Sokal E, et al. Size reduction of the donor liver is a safe way to alleviate the shortage of sizematched organs in pediatric liver transplantation. Ann Surg 1990; 211: 146-57.

9 Sokal EM, Veyckemans F, de Ville de Goyet J, et al. Liver transplantation in children less than 1 year of age 7 Pediatr 1990; 117: 205-10.

10 Sokal EM, Bustos R, Van Hoof F, Otte JB. Liver transplantation for hereditary tyrosinemia: early transplantation following patient's stabilisation. Transplantation 1993 (in press).

11 Krupp P, Gulich A, Timonenen P. Side-effects and safety of Sandimmune in long term treatment of renal transplant Sandimmune in long term treatment

12 O'Sullivan DP. Convulsions associated with cyclosporin A. BMF 1985; 290: 858 .

13 Adams DH, Ponsford S, Gunson B, et al. Neurological complications following liver transplantation. Lancet 1987; i: $949-51$

14 de Groen PC, Wiesner RH, Krom RA. Advanced liver failure predisposes to cyclosporine-induced central nervous svstem symptoms after liver transplantation. Transplant Proc 1989; 21: 2456 .

15 Mc Lung HJ, Sloan HR, Powers P, et al. Early changes in the permeability of the blood-brain barrier produced by toxins

16 de Groen PC. Cyclosporine, low-density lipoprotein, and cholesterol. Mayo Clin Proc 1988; 63: 1012-21.

17 Truwit CL, Denaro CP, Lake JR, DeMarco T. MR imaging of reversible cyclosporine A-induced neurotoxicity. $A \exists N^{\prime} R$ reversible cyclosp

18 Wallemacq PE, Lesne M, Otte JB. Cyclosporine monitoring by RIA and HPLC in liver transplantation: clinical correlation. Clinics in Transplantation 1987; 1 : 132-7.

19 Kunzendorf U, Brockmoller J, Jochimsen F, Keller F, Walz G, Offerman G. Cyclosporin metabolites and central nervous system toxicity. Lancet 1988; i: 1223

20 Famiglio L, Racusen L, Fivush B, Solez K, Fisher R. Central nervous system toxicity of cyclosporine in a rat model. Transplantation 1989; 48: 316-21.

21 Scheinman SJ, Reinitz ER, Petro G. Cyclosporine central neurotoxicity following renal transplantation. Report of a case using magnetic resonance images. Transplantation 1990; 49: 215 .

22 Deierhoi $M H$, Kalayoglu $M$, Sollinger $H W$, Belzer FO. Cyclosporine neurotoxicity in liver transplant recipients: report of three cases. Transplant Proc 1988; 20: 116-8.

23 Cames B, Rahier J, Burtomboy G, et al. Acute adenovirus hepatitis in liver transplant recipients. $\mathcal{F}$ Pediatr 1992; 120: 33-7. 